\title{
THE INFLUENCE OF SOCIO-ECONOMIC DEPRIVATION ON MULTIMORBIDITY: A SYSTEMATIC REVIEW
}

\author{
Micky Oloo Olutende ${ }^{1 i}$, \\ Elizabeth Mse $^{2}$, \\ Maximilla N. Wanzala ${ }^{3}$, \\ Edwin Kadima Wamukoya ${ }^{4}$ \\ ${ }^{1}$ Department of Health Promotion and Sports Science, \\ Masinde Muliro University of Science and Technology, \\ Kenya \\ ${ }^{2}$ Dr., Department of Health Promotion and Sports Science, \\ Masinde Muliro University of Science and Technology, \\ Kenya \\ ${ }^{3}$ Dr., Department of Public Health, \\ Masinde Muliro University of Science and Technology, \\ Kenya \\ ${ }_{4}^{4}$ Prof., Department of Public Health, \\ Masinde Muliro University of Science and Technology, \\ Kenya
}

\begin{abstract}
:
Introduction: Multimorbidity poses a current global health challenge due to its increasing prevalence and burden on individuals and health systems. Evidence suggests that more socially disadvantaged individuals share a disproportionate burden of multimorbidity. The evidence on the relationship between area-level socioeconomic disadvantage and multimorbidity is unclear. Thus, the aim of the current study is to synthesise evidence on the association between area-level socio-economic disadvantage and multimorbidity. Methods: A systematic review was conducted of published literature from inception to January 2020. Search strategy was applied to identify evidence on PubMed (Medline), Ovid (Medline, Embase, Psycinfo) and Web of Science. Studies were selected according to the inclusion and exclusion criteria. Newcastle Ottawa Scale for observational studies was used for quality assessment of included studies. Evidence was synthesised narratively. Results: We identified eight out of 2588 studies identified in the search as per the inclusion and exclusion criteria. Out of the eight studies, five studies confirmed a positive association between area-level socio-economic disadvantage and multimorbidity, two studies presented a negative association, and one study presented no association. Three studies found individuals in deprived areas to
\end{abstract}

i Correspondence: email micky.oloo.mf@gmail.com, micky.oloo.mf@gmail.com 
have higher multimorbidity than those in affluent areas. Two studies established that individuals in rural areas had higher multimorbidity than their urban counterparts. Two studies found individuals in urban areas to have a higher multimorbidity than those in rural areas. Conclusion: Evidence shows that association between area-level socioeconomic disadvantage and multimorbidity exist. Except for area of residence, clear positive associations were confirmed between area deprivation and multimorbidity.

Keywords: socio-economic deprivation, multimorbidity

\section{Introduction}

Multimorbidity, defined as the existence of two or more chronic conditions in an individual at the same time ( $\underline{1-5})$, is a current global challenge on the health care systems and a public health concern $(\underline{3}, \underline{6}, \underline{7})$. The conditions range across different chronic illnesses, disorders, and health problems (으). In the current review, the argument is based on multimorbidity as earlier defined with a focus on the individual as a whole in relation to primary health care. In contrast, co-morbidity which is commonly used interchangeably, is defined as the occurrence of medical conditions that are additional to an index disease in an individual. The distinction is due to the argument that comorbidity is more useful when the focus is on specialist care in regard to the index disease(匂). There is an increasing prevalence of multimorbidity that is attributed to reduced mortality from the advancements in the health care interventions. Among them includes medical care and technologies for early detection and treatment of conditions thus improved, life expectancy. These have resulted in an increasing size in the ageing population who contributes the greatest proportion of multimorbidity ( $\underline{3})$. In the highincome countries, the prevalence of multimorbidity ranges from $12.9 \%$ to $95.1 \%$ whereas in low-middle income countries it has not been well established ( $\underline{10})$. Outcomes of multimorbidity leads to complex health needs accounting for an increase in the proportion of health care workload and expenditure, therefore burdening health systems $(\underline{10}, \underline{11})$.

People with multi-morbidity are often at risk of receiving low quality, fragmented, costly and ineffective care (11-13). These are largely due to complex selfcare needs which affects accessibility, coordination and consultation timings, leading to multiple prescriptions, increase in unplanned hospital/facility use, difficulty in applying guidelines thus, conflicting treatment and advice from the care providers (14-19). Despite of the observed transition in disease burden and recognition of the prevalence of multimorbidities among the adult population, care guidelines, health systems, medical education and research has paid lesser attention to multimorbidity than single disease.

Understanding of the influence of health determinants on multimorbidity provides information for policy development in attempt to prevent and effectively manage multimorbidity through early identification of the at risk population for prevention of future health conditions (10). Evidence shows that social disadvantage is a key determinant of multimorbidity $(\underline{16}, \underline{20})$. Several studies have examined social inequalities in multimorbidity by measuring its variation according to socio-economic 
status, gender, age, education and demography. In high income countries, evidence has shown a high prevalence of multimorbidity among the population with higher ages, those with low income, low education and female sex (16, 21-23). In Australia variations in the prevalence of multimorbidity was observed across different age groups in the adult population (므). Studies examining association between multimorbidity and socioeconomic status (SES) have shown contrasting results according to country-level

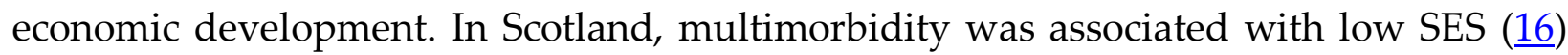
while in Bangladesh it was more associated with high SES (14).

With well documented evidence of individual level socioeconomic disadvantage and multimorbidity ( $(\underline{)})$, little is known about the impact of area-level social disadvantage on multimorbidity. However, research shows that it potentially increase the risk of multimorbidity and create barriers to treatment and care of the socially disadvantaged population (24). Evidence shows that multimorbidity is more prevalent in the socially deprived areas. In Scotland, $21 \%$ of the population living in poorer areas had multimorbidity as compared to $8.5 \%$ in affluent areas (20) $)$. Also in New Zealand, a study reported that multimorbidity was more prevalent among rural residents as compared to their urban counterparts (ㅌ5). Further, research shows that individuals in high socioeconomic position (SEP) neighbourhoods have ease of access to quality care facilities and more patient centred care for both prevention and management services and are well

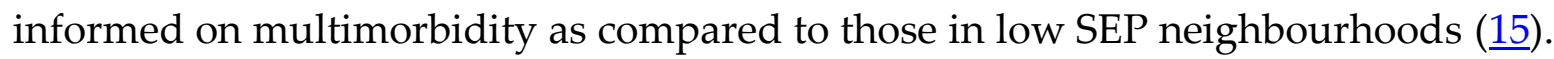

It is paramount to understand neighbourhood characteristics like socio-economic context which may have an independent influence on an individual's health and in this case may have an impact on the prevalence of multimorbidity. In addition to individual characteristics, neighbourhood level measures help to understand political, economic and cultural characteristics associated with population health. Evidence has shown an association between both neighbourhood economic disadvantage (26) and deprivation (27) and multimorbidity. These studies show that a person's neighbourhood may have an independent impact on their risk of multimorbidity potentially through availability and accessibility to health services, lack of social support services, infrastructure deprivation; poor transport networks, poor housing, lack of parks/greenspace and lack of healthy food stores with affordable prices. These factors affect attitudes towards health and health related behaviour which in turn increases the risks or hinder prevention, management and control of multimorbidity (르).

While there is significant evidence that shows that the prevalence of multimorbidity has an association with socioeconomic disadvantage and there is intervention and management challenges experienced in the health systems, available systematic reviews have only examined the association at individual level. Considering the complexities associated with socioeconomic disadvantage and multimorbidity, neighbourhood context would be important to enhance understanding and inform decision making. Therefore, the current review is the first one that specifically examine the association between area-level socioeconomic disadvantage and multimorbidity.

Socio-economic status has been observed as a major determinant of multimorbidity (므). Therefore, assessment of area level socioeconomic disadvantage may 
help to provide relevant information on neighbourhood characteristics and their influence on multimorbidity. This would provide information on area-level differences which may act as a key element in burden and differential health needs between areas to inform intervention. In the current review, our aim is to examine the literature to establish if there is an association between area-level socioeconomic disadvantage and multimorbidity. This information will help in the understanding of multimorbidity at neighbourhood-level which would inform decision making and allow for effective strategic planning for population-based prevention and management services across localities. Further, it would inform policy for equity and priority setting. Finally, it will provide information for further research.

\section{Research question}

Is there an association between area-level socioeconomic disadvantage and multiple morbidity?

\subsection{Objective of the study}

The objective of this study was to systematically identify the existing literature, critically appraise, synthesise and summarise the available information on the association between area-level socioeconomic disadvantage and multimorbidity.

\section{Methods}

\subsection{Search strategy}

Primary searches were systematically conducted in electronic databases using PubMed, Ovid (Medline, Embase, PsycInfo) and Web of Science platforms, illustrated in Figure 1. Relevant studies available on the 10th January 2020 and published from inception to July 2018 were identified and extracted from each database. The search strategy was comprehensive and included searches for each component namely; the context/neighbourhood, outcome and phenomenon/exposure (residence characteristics, multimorbidity, socioeconomic factors, inequality). They were performed separately using combination of key-terms and Medical Subject Headings (Thesaurus/MeSH/Emtree) and common keywords identified from existing literature were also used (20). See Appendix 1 for search terms. Using the Boolean terms, the search results were combined, initially developed in PubMed platform, then adapted and tailored to each database using Web of Science and Ovid platforms. Additionally, reference lists of selected studies were searched for additional studies that met inclusion criteria. Appendix one provides detailed search strategies for individual database. Expert support from a research librarian was sought to help in developing search strategy.

\subsection{Study selection}

The relevant studies identified through the search had their titles and abstracts retrieved and managed using bibliographic software Endnote version 7.0.2. Duplicates were 
identified and removed using an Endnote function. Further, manual cross checking and removal of duplicates that had been missed in the initial step of screening titles and abstracts was performed. One author (MO) screened all the papers by title and abstract and where necessary reviewed full text of the articles. To minimise bias, the second author (EM) screened $20 \%$ of the studies screened by the first reviewer to double check as per the recommendations for a systematic review (29). All potentially eligible articles were reviewed based on the inclusion and exclusion criteria by two authors ( $\mathrm{MO}$ and MW) independently and any disagreements were resolved through discussion. A third reviewer (EK) was also available as per the research protocol to resolve any disagreements. The selected studies had their full-texts retrieved for further examination to ascertain their eligibility for selection for inclusion in the review. Note worth, to ensure both authors have a uniform comprehension of the studies, only original studies published in English were considered for full text screening. Independent review of fulltexts by the two authors MO and EM was performed, disagreements were resolved through discussions. Studies excluded after full-text review were recorded and reasons for exclusion documented. A summary has been provided as per the PRISMA guidelines for reporting of a systematic review in Figure 1.

\subsection{Inclusion and exclusion criteria}

We included studies which applied quantitative research methods. We included studies that were published from inception up to January 2020. Language restriction was applied where only studies published in English were included. We also included articles whose study population was strictly adults from age of 18 years in any setting. Studies that measured socio-economic disadvantage at an area-level and multimorbidity as a primary outcome were included in the current review. We excluded qualitative studies, studies that measured socio-economic disadvantage at individual level, those with multimorbidity as an exposure, those that reported on co-morbidity rather than multimorbidity and those that addressed a single chronic disease.

\subsection{Data extraction}

A structured data extraction form was developed which addressed the study objectives, that enabled collection of comprehensive information on study characteristics for easy interpretation of results by both authors. The form was then piloted on $10 \%$ of the selected studies and relevant adjustments were made. Relevant information from the included studies was extracted by one reviewer (EK) and cross-checked by the second author (MW). Resolution of disagreements was addressed through discussion. The information extracted from the studies included study characteristics such as the title of the study, author names, year of publication and country, the population and study settings, age range of study participants, gender proportions of participants, study design, sample size, sampling method, the definitions and measurements of both exposure/phenomena and outcome and the number of chronic diseases included in the study. Additionally, key findings on the relationship between area-level socio-economic disadvantage and multimorbidity were extracted. Measures of relative risk and central estimates, 
sensitivity analysis within studies for potential bias, limitations and conclusions of individual studies were also extracted. For studies with more than one exposure variable, findings of each variable were extracted separately for the associations examined for in the study. All the variables analysed to establish the association of area level socioeconomic disadvantage were also extracted (see appendix 2 Data extraction form).

\subsection{Quality assessment}

Two authors ( $\mathrm{MO}$ and $\mathrm{EM}$ ) independently performed the methodological quality assessment of the studies included in the review to account for risk of bias. The assessment was done using the Newcastle-Ottawa Scale (NOS) which is a well-

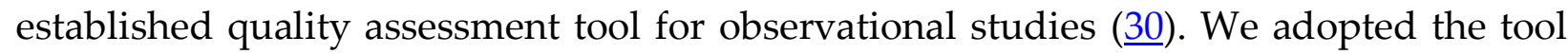
for cohort studies and a modified tool that suited the cross-sectional studies. The quality of the studies was assessed in three domains; selection bias, comparability and outcome measurement. For this review, Newcastle Ottawa Scale scores for cohort study were considered of good quality if the score was 4 in selection domain, 1 in the comparability domain and 2 or 3 in the outcome domain. Fair quality was of scores 2 or 3 in selection domain, 1 in comparability domain and 1 in the outcome domain. The rest were considered as poor quality. For cross-section studies, score 4 or 5 in selection criteria, score 1 lout of 2 in comparability and score $2 / 3$ out of 3 in outcome assessment domains were considered as good quality study, score 3 for selection criteria, score 1 for comparability and score 1 for outcome were considered as fair quality while all scores below the latter were considered to be of poor quality.

\subsection{Evidence synthesis}

Due to heterogeneity of the findings between the included studies, a meta-analysis was precluded. Instead, we synthesised and discussed the findings narratively. There were differences in exposures and exposure measurement of area-level socio-economic disadvantage, and the outcome which was number of and chronic diseases used to measure multimorbidity. There was also a difference in the methods of statistical analyses where some studies presented percentage prevalence while others performed logistic regression and presented Odds ratios. Furthermore, there was a variation in the characteristics of the population groups of focus. This paper was prepared based on the Preferred Reporting Items for Systematic Reviews and Meta-Analysis (PRISMA) checklist and guidelines (푸).

\section{Results}

A total of 2588 studies were identified from the electronic database searches. After removing duplicates by Endnote software and manual search, there were 1870 unique studies that were screened based on titles and abstracts and full text where necessary. Of these, 31 studies were identified as potentially eligible and underwent full-text assessment for eligibility. Eight studies met eligibility criteria and were selected for 
inclusion and data extraction in the review. Figure 1 below shows the process of study selection as per the PRISMA flowchart.

Figure 1: PRISMA flow chat

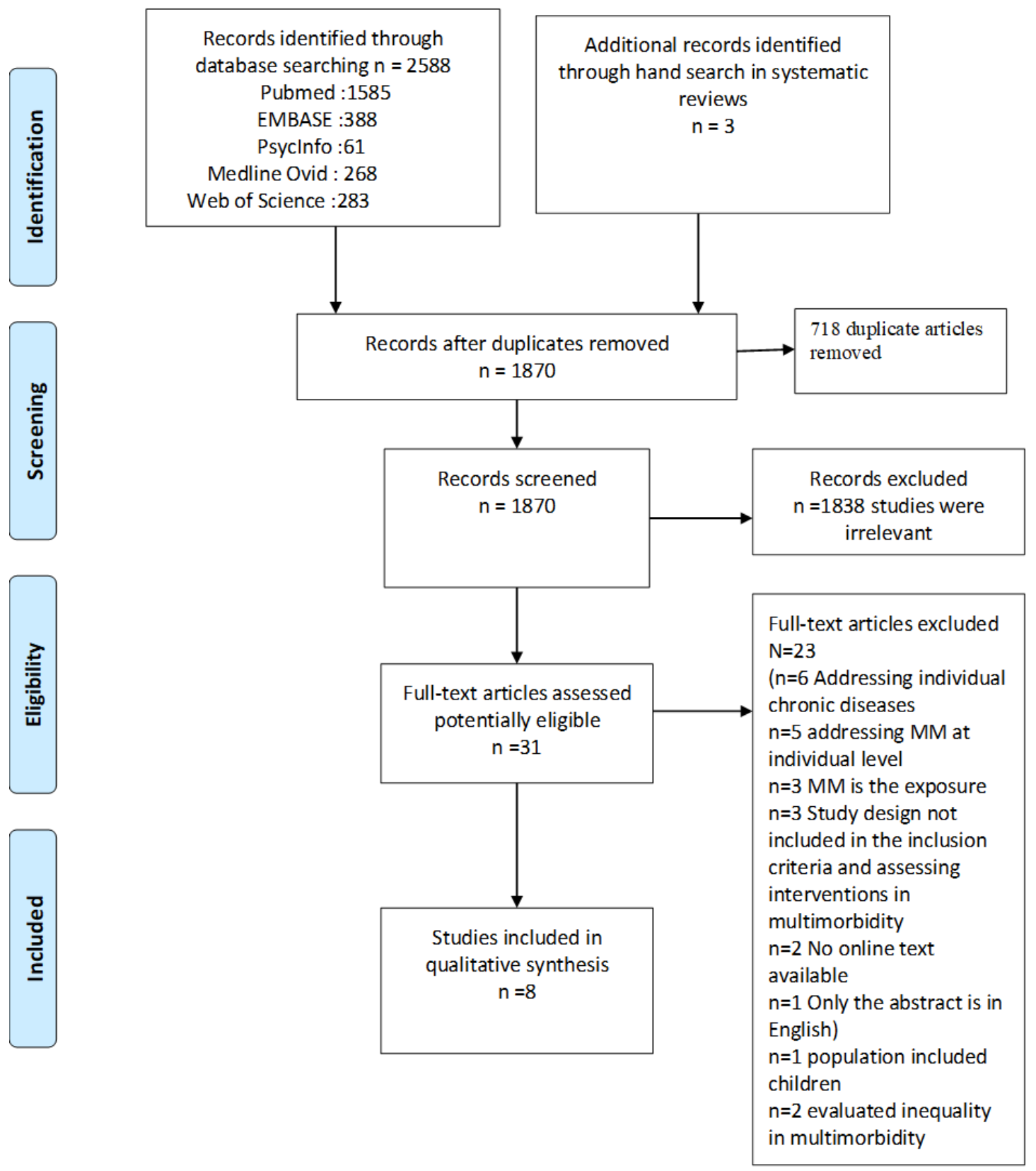

\section{Summary characteristics of selected studies}

Table 1 provides a summary of the characteristics of the eight selected studies. All the studies were published between 2011 and 2020. Five out of the eight studies were conducted in high-income countries, two studies were from upper-middle income country and one in low-income country. Two studies were conducted in UK/England ( $\underline{32}$,

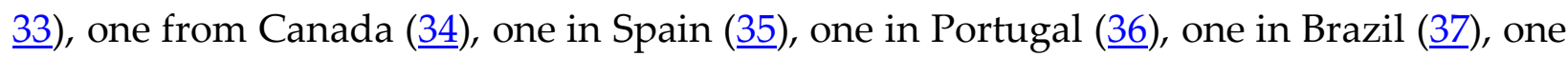

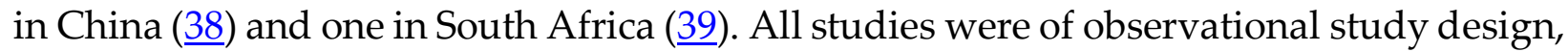


one retrospective cohort study and seven cross-section studies. Generally, recruitment of participants was through population-based primary care databases or regional or national surveys/census. Six studies examined adults above 18 years of age, one studied above 20 years of age and one studies more than 65 years of age. Four studies assessed area-level socio-economic disadvantage by measure of place of residence/residence characteristics, three assessed area level deprivation each utilising a different standard measurement tool. One study measured three exposures; state-level education, statelevel income and geographical area (urban/rural).

All the included studies measured multimorbidity as co-occurrence of two or more chronic diseases in the same individual. However, two of the studies further examined presence of three or more chronic health conditions within an individual. Ascertainment of multimorbidity was by use of objective sources which were health records from the General Practice that captured Doctor's diagnosis and was evident in four out of the eight studies. The other four relied on participants' self-report of the doctor-diagnosis of multiple chronic conditions which would likely be subjected to recall error. The number of chronic diseases listed in individual included studies ranged from 6 to 147 diseases as summarised in Table 1. 
Micky Oloo Olutende, Elizabeth Mse, Maximilla N. Wanzala, Edwin Kadima Wamukoya TRAINING SPORT COACHES FOR ATHLETES WITH INTELLECTUAL DISABILITIES: THE TEAMUP PROJECT

\begin{tabular}{|c|c|c|c|c|c|c|c|c|c|c|c|c|}
\hline $\begin{array}{l}\text { Study } \\
\text { Author, }\end{array}$ & $\begin{array}{l}\text { Study } \\
\text { design }\end{array}$ & Year & Country & $\begin{array}{c}\text { Study } \\
\text { Population }\end{array}$ & $\begin{array}{l}\text { Study } \\
\text { sample } \\
\text { (N) }\end{array}$ & sex & $\begin{array}{c}\text { Age } \\
\text { (years) }\end{array}$ & $\begin{array}{l}\text { Socio- } \\
\text { economic } \\
\text { Exposure }\end{array}$ & $\begin{array}{c}\text { Measurement } \\
\text { of Exposure/ } \\
\text { socioeconomic } \\
\text { disadvantage }\end{array}$ & $\begin{array}{l}\text { Definition of } \\
\text { Multimorbidity } \\
\text { as outcome }\end{array}$ & $\begin{array}{l}\text { Ascertainment } \\
\text { of } \\
\text { multimorbidity }\end{array}$ & $\begin{array}{c}\text { Total } \\
\text { number of } \\
\text { diseases }\end{array}$ \\
\hline Salisbury & $\begin{array}{l}\text { Retro- } \\
\text { spective } \\
\text { cohort } \\
\text { study }\end{array}$ & 2011 & $\begin{array}{l}\text { United } \\
\text { Kingdom }\end{array}$ & $\begin{array}{l}\text { Adult patients } \\
\text { from } 182 \\
\text { practices in } \\
\text { England } \\
\text { contributing } \\
\text { data to the } \\
\text { General } \\
\text { Practice } \\
\text { Research } \\
\text { Database } \\
\text { (GPRD). }\end{array}$ & 99,997 & NR & $>18$ & $\begin{array}{l}\text { Area } \\
\text { deprivation. }\end{array}$ & $\begin{array}{l}\text { Townsend } \\
\text { scores derived } \\
\text { from the } \\
\text { patient's } \\
\text { postcode and } \\
\text { national } \\
\text { quintiles } \\
\text { using } 2001 \\
\text { census. }\end{array}$ & $\begin{array}{l}\text { patient who, } \\
\text { on the index date, } \\
\text { had more than } \\
\text { one of } 17 \\
\text { important } \\
\text { chronic } \\
\text { conditions for } \\
\text { which care is } \\
\text { incentivised } \\
\text { under the QOF }\end{array}$ & GP records & 17 \\
\hline Barnette & $\begin{array}{l}\text { Cross- } \\
\text { sectional }\end{array}$ & 2012 & $\begin{array}{l}\text { United } \\
\text { Kingdom } \\
\text { (UK) }\end{array}$ & $\begin{array}{l}\text { Patients of any } \\
\text { age registered } \\
\text { with one of } \\
314 \text { GP } \\
\text { practices, } \\
\text { covering one } \\
\text { third of the } \\
\text { Scottish } \\
\text { population }\end{array}$ & $1,751,841$ & 50.5 & $>18$ & $\begin{array}{l}\text { Area } \\
\text { deprivation }\end{array}$ & $\begin{array}{l}\text { Carstairs } \\
\text { Deprivation } \\
\text { Index; based on } \\
\text { census } \\
\text { information for } \\
\text { postcode } \\
\text { sectors }\end{array}$ & $\begin{array}{l}\text { Presence of } 2 \text { or } \\
\text { more chronic } \\
\text { conditions in one } \\
\text { patient }\end{array}$ & $\begin{array}{l}\text { GP medical } \\
\text { records }\end{array}$ & 40 \\
\hline Alaba & $\begin{array}{l}\text { Cross- } \\
\text { sectional }\end{array}$ & 2013 & $\begin{array}{l}\text { South } \\
\text { Africa }\end{array}$ & $\begin{array}{l}\text { South African } \\
\text { adults aged } \\
\text { above } 18 \text { from } \\
53 \text { council } \\
\text { districts } \\
\end{array}$ & 16,638 & 61 & $>18$ & $\begin{array}{l}\text { Residential } \\
\text { area }\end{array}$ & $\begin{array}{l}\text { Rural and } \\
\text { urban }\end{array}$ & $\begin{array}{l}\text { Presence of } 2 \text { or } \\
\text { more chronic } \\
\text { diseases }\end{array}$ & GPs records & 6 \\
\hline Orueta & $\begin{array}{l}\text { Cross- } \\
\text { sectional }\end{array}$ & 2013 & Spain & $\begin{array}{l}\text { Adults age } \\
\text { above } 65 \text { years } \\
\text { covered by } \\
\text { public health } \\
\text { insurance in } \\
\text { the Basque } \\
\text { country }\end{array}$ & 452,698 & NR & $>65$ & $\begin{array}{l}\text { Area-based } \\
\text { deprivation }\end{array}$ & $\begin{array}{l}\text { Geographical } \\
\text { deprivation } \\
\text { index based on } \\
\text { census } \\
\text { information for } \\
\text { small }\end{array}$ & $\begin{array}{l}\text { Co-occurrence of } \\
2 \text { or more health } \\
\text { problems in the } \\
\text { same person }\end{array}$ & NR & 47 \\
\hline
\end{tabular}


Micky Oloo Olutende, Elizabeth Mse, Maximilla N. Wanzala, Edwin Kadima Wamukoya

TRAINING SPORT COACHES FOR ATHLETES WITH INTELLECTUAL DISABILITIES: THE TEAMUP PROJECT

\begin{tabular}{|c|c|c|c|c|c|c|c|c|c|c|c|c|}
\hline $\begin{array}{l}\text { Study } \\
\text { Author, }\end{array}$ & $\begin{array}{l}\text { Study } \\
\text { design }\end{array}$ & Year & Country & $\begin{array}{c}\text { Study } \\
\text { Population }\end{array}$ & $\begin{array}{l}\text { Study } \\
\text { sample } \\
\text { (N) }\end{array}$ & $\operatorname{sex}$ & $\begin{array}{c}\text { Age } \\
\text { (years) }\end{array}$ & $\begin{array}{c}\text { Socio- } \\
\text { economic } \\
\text { Exposure }\end{array}$ & $\begin{array}{c}\text { Measurement } \\
\text { of Exposure/ } \\
\text { socioeconomic } \\
\text { disadvantage } \\
\end{array}$ & $\begin{array}{l}\text { Definition of } \\
\text { Multimorbidity } \\
\text { as outcome }\end{array}$ & $\begin{array}{l}\text { Ascertainment } \\
\text { of } \\
\text { multimorbidity }\end{array}$ & $\begin{array}{c}\text { Total } \\
\text { number of } \\
\text { diseases }\end{array}$ \\
\hline & & & & & & & & & $\begin{array}{l}\text { geographical } \\
\text { units }\end{array}$ & & & \\
\hline Prazeres & $\begin{array}{l}\text { Cross- } \\
\text { sectional }\end{array}$ & 2015 & Portugal & $\begin{array}{l}\text { Portuguese } \\
\text { population } \\
\text { across the five } \\
\text { mainland } \\
\text { Portugal } \\
\text { Healthcare } \\
\text { Administrative } \\
\text { Regions, } \\
\text { attending } \\
\text { primary health } \\
\text { care }\end{array}$ & 1,293 & 64.2 & $>18$ & $\begin{array}{l}\text { Residential } \\
\text { areas }\end{array}$ & $\begin{array}{l}\text { Rural and } \\
\text { urban based on } \\
\text { the } \\
\text { administrative } \\
\text { regions }\end{array}$ & $\begin{array}{l}\text { presence of } 2 \text { or } \\
\text { more chronic } \\
\text { diseases }\end{array}$ & $\begin{array}{l}\text { Self-report and } \\
\text { medical records }\end{array}$ & 147 \\
\hline Robert & $\begin{array}{l}\text { Cross- } \\
\text { sectional }\end{array}$ & 2015 & Canada & $\begin{array}{l}\text { Canadian } \\
\text { population } \\
\text { aged } 20 \text { and } \\
\text { older from the } \\
2011 / 12 \\
\text { Canadian } \\
\text { Community } \\
\text { Health Survey } \\
\text { (CCHS). }\end{array}$ & 105,416 & 50.9 & $>20$ & $\begin{array}{l}\text { Area of } \\
\text { residence }\end{array}$ & $\begin{array}{l}\text { Rural and } \\
\text { Urban }\end{array}$ & $\begin{array}{l}\text { having two } \\
\text { or more }(2+) \text { and } \\
\text { three or more } \\
\text { chronic } \\
\text { diseases }(3+) \\
\text { from a list of } \\
\text { nine. }\end{array}$ & Self-reported & 9 \\
\hline Wang & $\begin{array}{l}\text { Cross- } \\
\text { sectional }\end{array}$ & 2015 & China & $\begin{array}{l}\text { Adult } \\
\text { residents in } \\
\text { Jilin Province, } \\
\text { North-Eastern } \\
\text { China from } \\
\text { June } 2012 \text { to } \\
\text { August } 2012 \text {. }\end{array}$ & 21,435 & NR & $>18$ & $\begin{array}{l}\text { Place of } \\
\text { residence }\end{array}$ & $\begin{array}{l}\text { Rural and } \\
\text { Urban }\end{array}$ & $\begin{array}{l}\text { Co-occurrence of } \\
\text { two or more } \\
\text { chronic diseases } \\
\text { within one } \\
\text { person in the past } \\
12 \text { months }\end{array}$ & Self-reported & 18 \\
\hline Nunes & $\begin{array}{l}\text { Cross- } \\
\text { sectional }\end{array}$ & 2017 & Brazil & $\begin{array}{l}\text { People living } \\
\text { in permanent } \\
\text { housing, } \\
\text { located in }\end{array}$ & 60,202 & $55.1 \%$ & $>18$ & $\begin{array}{l}\text { State-level } \\
\text { education } \\
\text { level }\end{array}$ & $\begin{array}{l}\text { State-level } \\
\text { education in } \\
\text { terciles- } \\
\text { proportion of }\end{array}$ & $\begin{array}{l}\geq 2 \text { and } \geq 3 \\
\text { morbidities }\end{array}$ & Self-reported & 22 \\
\hline
\end{tabular}


Micky Oloo Olutende, Elizabeth Mse, Maximilla N. Wanzala, Edwin Kadima Wamukoya

TRAINING SPORT COACHES FOR ATHLETES WITH INTELLECTUAL DISABILITIES: THE TEAMUP PROJECT

\begin{tabular}{|c|c|c|c|c|c|c|c|c|c|c|c|c|}
\hline $\begin{array}{c}\text { Study } \\
\text { Author, }\end{array}$ & $\begin{array}{l}\text { Study } \\
\text { design }\end{array}$ & Year & Country & $\begin{array}{c}\text { Study } \\
\text { Population }\end{array}$ & $\begin{array}{l}\text { Study } \\
\text { sample } \\
\text { (N) }\end{array}$ & sex & $\begin{array}{c}\text { Age } \\
\text { (years) }\end{array}$ & $\begin{array}{c}\text { Socio- } \\
\text { economic } \\
\text { Exposure }\end{array}$ & $\begin{array}{c}\begin{array}{c}\text { Measurement } \\
\text { of Exposure/ } \\
\text { socioeconomic } \\
\text { disadvantage }\end{array} \\
\end{array}$ & $\begin{array}{c}\text { Definition of } \\
\text { Multimorbidity } \\
\text { as outcome }\end{array}$ & $\begin{array}{l}\text { Ascertainment } \\
\text { of } \\
\text { multimorbidity }\end{array}$ & $\begin{array}{c}\text { Total } \\
\text { number of } \\
\text { diseases }\end{array}$ \\
\hline & & & & $\begin{array}{l}\text { urban or rural } \\
\text { areas, covering } \\
\text { the country's } \\
\text { five major } \\
\text { geographical } \\
\text { regions, its } 26 \\
\text { states } \\
\text { and Federal } \\
\text { District. }\end{array}$ & & & & $\begin{array}{l}\text { State-level } \\
\text { income } \\
\text { Geographical } \\
\text { area }\end{array}$ & $\begin{array}{l}\text { literacy rate } \\
\text { obtained from } \\
\text { IBGE } 2010 \\
\text { state-level } \\
\text { Income in } \\
\text { terciles } \\
\text { (nominal } \\
\text { income per } \\
\text { capita-average } \\
\text { monthly } \\
\text { value-in } \\
\text { permanent } \\
\text { private housing } \\
\text { obtained from } \\
\text { IBGE 2010). } \\
\text { Rural and } \\
\text { urban }\end{array}$ & & & \\
\hline
\end{tabular}

\subsection{Quality Assessment summary}

The articles included in the review had varying quality where two of them had good quality, four were of moderate quality and two were considered to have poor quality based on the Newcastle Ottawa Scale (NOS) assessment (see Table 2). The two studies of poor quality did not perform regression modelling to control for confounding which led to poor score in the comparability domain. Thus, the main limitation was lack of information to support comparability of the two studies. Additionally, it was observed that there was lack of information on non-responders which can be attributed to study designs.

Details of each study's methodological quality assessment using Newcastle Ottawa Scale (NOS) are presented in Table 2. In the review there was only one cohort study and seven cross-sectional studies. The retrospective cohort study was of fair quality. 
Micky Oloo Olutende, Elizabeth Mse, Maximilla N. Wanzala, Edwin Kadima Wamukoya TRAINING SPORT COACHES FOR ATHLETES WITH INTELLECTUAL DISABILITIES: THE TEAMUP PROJECT

Table 2: Quality Assessment of included studies

\begin{tabular}{|c|c|c|c|c|c|c|c|c|c|c|}
\hline \multicolumn{11}{|c|}{ Retrospective cohort study } \\
\hline \multirow[t]{2}{*}{ Study } & \multicolumn{4}{|c|}{ Selection } & \multirow[b]{2}{*}{$\begin{array}{c}\text { Comparability } \\
\text { On basis of } \\
\text { design or } \\
\text { analysis } \\
\text { controlled for } \\
\text { confounders }\end{array}$} & \multicolumn{3}{|c|}{ Outcome } & \multicolumn{2}{|c|}{ Overall } \\
\hline & $\begin{array}{l}\text { Representativeness } \\
\text { of the exposed cohort }\end{array}$ & $\begin{array}{l}\text { Selection } \\
\text { of the } \\
\text { non- } \\
\text { exposed } \\
\text { cohort }\end{array}$ & $\begin{array}{l}\text { Ascertainment } \\
\text { of exposure }\end{array}$ & $\begin{array}{l}\text { Demonstration } \\
\text { that outcome of } \\
\text { interest was not } \\
\text { present at start } \\
\text { of study }\end{array}$ & & $\begin{array}{l}\text { Assessment } \\
\text { of outcome }\end{array}$ & $\begin{array}{l}\text { Was } \\
\text { follow-up } \\
\text { long } \\
\text { enough for } \\
\text { outcomes } \\
\text { to occur }\end{array}$ & $\begin{array}{l}\text { Adequacy } \\
\text { of follow- } \\
\text { up of } \\
\text { cohorts }\end{array}$ & & \\
\hline $\begin{array}{l}\text { Salisbury, } \\
2011\end{array}$ & $x$ & $x$ & $x$ & & $x$ & $x$ & & & $5 / 8$ & Fair \\
\hline
\end{tabular}

\begin{tabular}{|c|c|c|c|c|c|c|c|c|c|}
\hline \multicolumn{10}{|c|}{ Cross-sectional studies } \\
\hline \multirow[t]{2}{*}{ Study } & \multicolumn{4}{|c|}{$\begin{array}{c}\text { Selection } \\
\text { (Maximum } 5 \text { stars) }\end{array}$} & \multirow{2}{*}{$\begin{array}{c}\begin{array}{c}\text { Comparability } \\
\text { (Maximum } 2 \text { stars) }\end{array} \\
\text { Comparability }\end{array}$} & \multicolumn{2}{|c|}{$\begin{array}{c}\text { Outcome } \\
\text { (Maximum } 3 \text { stars) }\end{array}$} & \multicolumn{2}{|c|}{ Overall } \\
\hline & $\begin{array}{l}\text { Representativeness } \\
\text { of the sample }\end{array}$ & $\begin{array}{l}\text { Sample } \\
\text { size }\end{array}$ & $\begin{array}{c}\text { Non- } \\
\text { respondents }\end{array}$ & $\begin{array}{l}\text { Ascertainment } \\
\text { of the exposure } \\
\text { (risk factor) }\end{array}$ & & $\begin{array}{c}\text { Assessment } \\
\text { of the } \\
\text { outcome }\end{array}$ & Statistical test & Score & Grade \\
\hline $\begin{array}{l}\text { Barnette, } \\
2012\end{array}$ & & $\mathrm{x}$ & & $x x$ & & $\mathrm{x}$ & & $4 / 10$ & Poor \\
\hline $\begin{array}{l}\text { Alaba, } \\
2013 \\
\end{array}$ & $\mathrm{x}$ & $\mathrm{x}$ & & $\mathrm{x}$ & $\mathrm{x}$ & $\mathrm{x}$ & $\mathrm{x}$ & $6 / 10$ & Fair \\
\hline $\begin{array}{l}\text { Orueta, } \\
2013 \\
\end{array}$ & & $\mathrm{x}$ & $\mathrm{x}$ & $x x$ & & $\mathrm{x}$ & & $5 / 10$ & poor \\
\hline $\begin{array}{l}\text { Prazeres, } \\
2015 \\
\end{array}$ & $\mathrm{x}$ & & & $x$ & $x$ & $x$ & $x$ & $5 / 10$ & Fair \\
\hline $\begin{array}{l}\text { Robert, } \\
2015 \\
\end{array}$ & $x$ & $\mathrm{x}$ & & $\mathrm{x}$ & $\mathrm{x}$ & $\mathrm{x}$ & $\mathrm{x}$ & $6 / 10$ & Fair \\
\hline $\begin{array}{l}\text { Wang, } \\
2015\end{array}$ & $\mathrm{x}$ & $\mathrm{x}$ & $\mathrm{x}$ & $\mathrm{x}$ & $\mathrm{x}$ & $\mathrm{x}$ & $\mathrm{x}$ & $7 / 10$ & Good \\
\hline $\begin{array}{l}\text { Nunes, } \\
2017\end{array}$ & $\mathrm{x}$ & $\mathrm{x}$ & $\mathrm{x}$ & $x$ & $x$ & $x$ & $x$ & $7 / 10$ & Good \\
\hline
\end{tabular}




\subsection{Relationship between area deprivation and multimorbidity}

Three of the included studies assessed the association between area-based deprivation and multimorbidity ( $\underline{32}, \underline{33}, \underline{35})$. One of which was the only cohort study and of retrospective design, had a sample population of 99,997 participants and reported Odds Ratio (OR) and $95 \%$ Confidence Interval for the association between area-level deprivation and multimorbidity (32). The other two studies were of

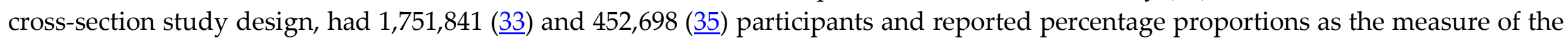
association. The cohort study by Salisbury et al, 2011 was considered to be of fair methodological quality whereas Orueta, 2013 and Barnett et al 2013 were considered of poor methodological quality. Regardless of quality and design variations, the studies reported findings of effect estimates that suggested that there was a relationship between area-based deprivation and multimorbidity. One study reported an OR of $2.08(95 \%$ CI 1.95, 2.22) of having multimorbidity with a $\mathrm{p}<0.001$ for individuals in deprived areas compared to those in affluent areas. Barnett reported percentage prevalence of multimorbidity as $19.5 \%(19.3,19.6)$ for individuals in affluent areas compared to $24.1 \%(23.9,24.4)$ among their counterparts in the deprived areas. Additionally, the study provides information that shows an increase in prevalence of multimorbidity with increasing scale of deprivation with a $\mathrm{p}<0.0001$ difference between categ ories. On the other hand, Orueta reported the average prevalence of multimorbidity in deprived areas for a population above 65 years of age to be $66.11 \%(65.97,66.25)$. A further assessment reported a stepwise increase in prevalence from least deprived areas ranging from $60.22 \%$ $(59.91,60.54)$ to most deprived areas 69.94\% $(69.64,70.25)$ (Table 3). Even though the two studies had a substantial difference in age characteristic of the participants, they had similar quality of study according to Newcastle Ottawa Scale, See Table 2. All the studies reported that there was an association between area-deprivation and multimorbidity.

\subsection{Relationship between area of residence and multimorbidity}

More than half of the included studies assessed the association between area of residence ( $\underline{34}, \underline{36}, \underline{37} \underline{39}, \underline{40})$, also referred to as geographical area by Nunes ( $\underline{37})$, and multimorbidity. A total sample of 204,984 individuals were analysed for this association. Two of the studies were found to be of good quality and the other three were all found to be of fair methodological quality. All the five studies reported evidence of association between area of residence and multimorbidity. They all analysed their data using logistic regression

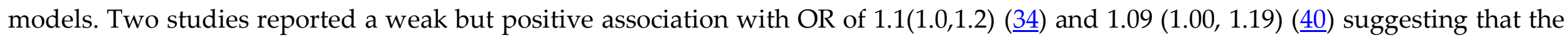
odds of multimorbidity was higher among rural residents compared to urban residents. In Nunes et al and Alaba studies, they reported a negative association between area of residence and multimorbidity, OR $0.86(0.80,0.92)$ and OR $0.65(0.46,0.93)$ p $<0.05$ respectively, showing that the odds of multimorbidity was higher among residents in urban areas compared to those who resided in rural areas. In contrast, Prazeres reported OR of $1.0(0.8,1.3)$ suggesting no association between area of residence and multimorbidity (Table 3). 


\subsection{Relationship between state-level education and multimorbidity}

Only one study (37) assessed the association between contextual education level at state level and multimorbidity. The study was of good methodological quality with an analysed sample size of 60,202 individuals in a middle-income country. The study reported OR of $0.83(0.72,0.96) \mathrm{P}<0.05$ showing that higher odds of multimorbidity were observed among individuals in high education-level states than those in low-education states (Table 3).

\subsection{Relationship between state-level income and multimorbidity}

There was a study that examined state-level income as a socio-economic disadvantage and multimorbidity (37) which was one of the studies considered to be of good quality as afore mentioned. The study examined the relationship between state level income and multimorbidity and reported findings that revealed a negative association with OR of $0.82(0.71,0.95)$ p $<0.05$ showing that the odds of multimorbidity was lower in individuals from states with low income compared to those individuals from states with high income.

Table 3: Summary of findings

\begin{tabular}{|c|c|c|c|c|c|c|}
\hline Study & $\begin{array}{c}\text { Analysed } \\
\text { sample size }\end{array}$ & Exposure & Outcome & $\begin{array}{l}\text { Measure of } \\
\text { association }\end{array}$ & $\begin{array}{c}\text { Effect and Uncertainty estimates OR } \\
\text { and CI }\end{array}$ & Covariates adjusted for \\
\hline $\begin{array}{l}\text { Salisbury, } \\
2011\end{array}$ & 99997 & $\begin{array}{c}\text { Area } \\
\text { deprivation }\end{array}$ & Multimorbidity & Odds ratio & $\begin{array}{l}\text { Most deprived compared to least } \\
\text { deprived } \\
2.08[95 \% \mathrm{CI}=1.95 \text { to } 2.22] \mathrm{p}<0.001\end{array}$ & Age and sex \\
\hline $\begin{array}{l}\text { Barnett, } \\
2012\end{array}$ & 1751841 & $\begin{array}{l}\text { Area-based } \\
\text { deprivation }\end{array}$ & Multimorbidity & $\begin{array}{l}\text { Percentage } \\
\text { prevalence }\end{array}$ & 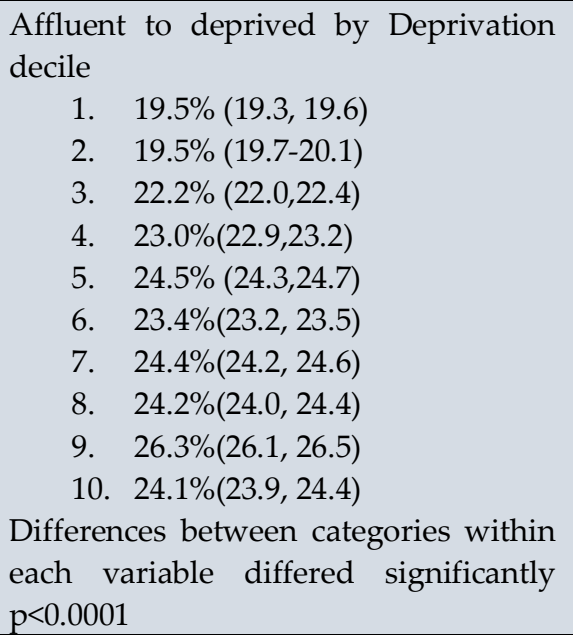 & Not Reported \\
\hline
\end{tabular}


Micky Oloo Olutende, Elizabeth Mse, Maximilla N. Wanzala, Edwin Kadima Wamukoya TRAINING SPORT COACHES FOR ATHLETES WITH INTELLECTUAL DISABILITIES: THE TEAMUP PROJECT

\begin{tabular}{|c|c|c|c|c|c|c|}
\hline $\begin{array}{l}\text { Alaba, } \\
2013\end{array}$ & 166338 & $\begin{array}{l}\text { Place of } \\
\text { residence }\end{array}$ & Multimorbidity & Odds ratio & $\begin{array}{l}\text { Crude } 0.78(0.58,1.05) \\
\text { Adjusted } 0.65(0.46,0.93) \mathrm{p}<0.05\end{array}$ & Sex, age, race, education and residence area \\
\hline $\begin{array}{l}\text { Orueta, } \\
2013\end{array}$ & 452698 & $\begin{array}{l}\text { Area-based } \\
\text { deprivation }\end{array}$ & Multimorbidity & $\begin{array}{l}\text { Percentage } \\
\text { prevalence }\end{array}$ & $\begin{array}{l}\text { Deprivation index } \\
\text { All deprived areas } 66.11 \%(65.97-66.25) \\
\text { DI } 160.22 \%(59.91-60.54) \\
\text { DI } 265.33 \%(65.03-65.64) \\
\text { DI } 367.63 \%(67.33-67.94) \\
\text { DI } 467.86 \%(67.56-68.16) \\
\text { DI } 569.94 \%(69.64-70.25 \\
\text { Significance value not reported }\end{array}$ & Not reported \\
\hline $\begin{array}{l}\text { Prazeres, } \\
2015\end{array}$ & 1293 & $\begin{array}{l}\text { Area of } \\
\text { residence }\end{array}$ & Multimorbidity & Odds ratio & $\begin{array}{l}\text { Place of residence } \\
\text { Rural compared to Urban } \\
\text { Crude. Not reported } \\
\begin{array}{l}\text { Adjusted }>2 \text { diseases } 1.0(0.8,1.3) \\
\text { p }<0.746 \\
\text { Adjusted }>3 \text { diseases } 1.2(0.9 \text { to } 1.5) \\
\text { p }<0.157\end{array}\end{array}$ & $\begin{array}{l}\text { Age, sex, education, living arrangement, marita } \\
\text { status }\end{array}$ \\
\hline $\begin{array}{l}\text { Robert, } \\
2015\end{array}$ & 105,416 & $\begin{array}{l}\text { Place of } \\
\text { residence }\end{array}$ & Multimorbidity & Odds ratio & $\begin{array}{l}\text { Residence area } \\
\text { Crude 1.2(1.1,1.3) Adjusted 1.1(1.0,1.2) } \\
\text { Rural compared to Urban } \\
\text { Significance value } \mathrm{p}<0.05\end{array}$ & Age and sex \\
\hline $\begin{array}{l}\text { Wang, } \\
2015\end{array}$ & 21435 & $\begin{array}{l}\text { Place of } \\
\text { residence }\end{array}$ & Multimorbidity & Odds ratio & $\begin{array}{l}\text { Residence area } \\
\text { Crude1.35 (1.25, 1.44) Adjusted } 1.09 \\
(1.00,1.19) \\
\text { P-value }<0.05 \\
\text { Rural compared to Urban }\end{array}$ & $\begin{array}{l}\text { Age, gender, place of residence, level of education, } \\
\text { income class, smoking status, body mass index, } \\
\text { psychological distress and utilization of primary } \\
\text { care facilities }\end{array}$ \\
\hline $\begin{array}{l}\text { Nunes, } \\
2017\end{array}$ & 60202 & $\begin{array}{l}\text { State-level } \\
\text { income } \\
\text { State-level } \\
\text { education }\end{array}$ & Multimorbidity & Odds ratio & $\begin{array}{l}\text { State-level income (Reference High) } \\
\text { Two or more diseases } \\
\text { Middle } 0.89(0.77,1.04) \\
\text { Low } 0.82(0.71,0.95) \\
\text { Three or more diseases } \\
\text { Middle } 0.88(0.73,1.05) \\
\text { Low } 0.75(0.63,0.89) \\
\text { State-level education (Reference high) } \\
\text { Two or more diseases }\end{array}$ & $\begin{array}{l}\text { Sex, age, skin colour, wealth index State income, } \\
\text { state education level and place of residence, }\end{array}$ \\
\hline
\end{tabular}


Micky Oloo Olutende, Elizabeth Mse, Maximilla N. Wanzala, Edwin Kadima Wamukoya TRAINING SPORT COACHES FOR ATHLETES WITH INTELLECTUAL DISABILITIES: THE TEAMUP PROJECT

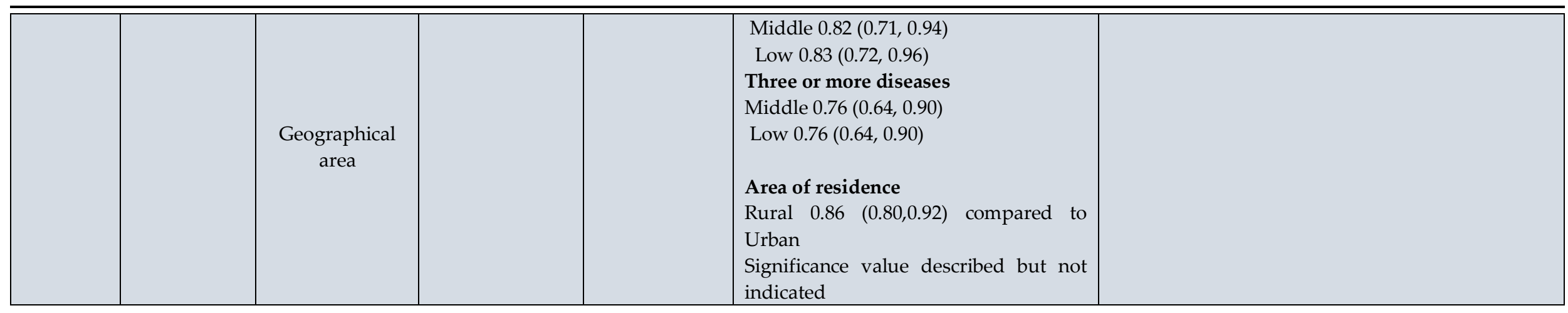




\section{Discussion}

We identified few studies that examined the relationship between area-level socioeconomic disadvantage and multimorbidity. All included studies were published between 2011 and 2018. Thus, this review highlights that there is recent data on area-level socioeconomic disadvantage and multimorbidity. Generally, evidence showed that there was an association between area-level socio-economic disadvantage and multimorbidity. Area deprivation had consistent positive association, whereas area of residence had inconsistencies in the direction of its association with multimorbidity. Both state-level income and state-level education revealed a counterintuitive association. Included studies had a variation in methodological quality with most of the included studies found to be of fair quality. Both good and poor-quality studies did not substantially lead to variation in the results.

The strengths of the current review were that it is the first to assess, synthesise and evaluate specific and available evidence on association between multimorbidity and specifically area-level socioeconomic disadvantage. We ensured a comprehensive and maximum coverage of articles by performing a broad search in five electronic bibliographic databases utilising a comprehensive list of search terms. Furthermore, we performed a manual search through citation references. However, there were limitations and the review may have missed out on relevant studies due to the authors' language restriction to studies published in English only, that may be available only in grey literature or that would be due to publication bias. Studies included in the review were more from high income countries compared to those from middle and low-income countries. Further, heterogeneity in the measurement and analysis of socio-economic disadvantage across the included studies limits comparability across studies thus inability to perform a meta-analysis, but a presentation of a narrative synthesis of results. Nonetheless, the findings in the current review, support conclusions from existing systematic review that have reported the association between area-based socioeconomic disadvantage and multimorbidity (20). However, the previous studies did not specifically address area-level socioeconomic disadvantage and multimorbidity. It was also observed that included studies were more limited to cross-sectional study design using mainly a section of the population that visited primary health care centres and not the general population. This enabled investigation involving large study populations within a short period of time to provide information on the prevalence of multimorbidity and information on relationship between the socioeconomic disadvantage and multimorbidity, thus, relevant for generating a hypothesis. However, the prevalence estimates and descriptive information provided by the included studies, mostly crosssectional studies may not allow for in-depth understanding of whether patients get exposed to the area-level socioeconomic disadvantage before they develop multiple chronic diseases. Thus, prospective cohort studies may be more appropriate to establish temporality or causal mechanism.

There was substantial heterogeneity between included studies and it was a challenge that was also reported in existing systematic review (20)$)$. There was a variation 
in the study sample populations' characteristics especially age groups. It is documented that most studies on multimorbidity have focused on older people (40). Notably, one of the included studies assessed a sample whose participants were either 65 years of age or above (41), a population that has been documented to have the highest prevalence of multimorbidity (9). Thus, results lack generalisability across age groups of the adult population. Further, another study assessed a sample of participants 20 years of age and above whereas majority of the included studies assessed participants of 18 years of age and above which is generally considered a standard measure for adult population therefore allows for generalisability of findings.

Further, there was a variation in the applied measures of area-based deprivation as an exposure. One study used Townsend scores derived from the patient's postcode and national quintiles using 2001 census (11). The other study used Carstairs Deprivation Index; based on census information for postcode sectors (16) and one used Geographical Deprivation Index based on census information for small geographical units (느). Thus, this may affect the consistency of the results. Moreover, different statistical methods were used in the analysis of the findings where some studies presented percentage prevalence while others presented odds ratios. There was a variation in the variables controlled for confounding between studies which may have affected individual study findings. Hence a meta-analysis was not feasible also due to this reason.

Collectively, seven out of eight included studies presented evidence of association between area-level socio-economic disadvantage and multimorbidity. However, the studies were of two study designs and types of exposures varied between studies. For studies assessing area deprivation, evidence from the cross-sectional studies reported a consistent increase in prevalence of multimorbidity with varying categories of area deprivation from affluent areas to deprived areas and from least deprived to highly deprived areas. The findings were supported by the results from a more robust retrospective cohort study design that also reported a positive association between area deprivation and multimorbidity with a stronger magnitude of association. Therefore, they consistently suggested that residents of deprived areas were more likely to develop multiple chronic diseases compared to residents of affluent areas. Noteworthy, all the studies were conducted in developed countries therefore may not be a true reflection of findings in low and middle-income countries.

Studies that examined area of residence reported use of rurality scales depending on the country of study. This exposure presented mixed results. The results showed inconsistencies in the association between area of residence and multimorbidity with a variation in the direction and magnitude of association. Some studies reported a positive association with findings showing an increase in the odds of developing multimorbidity among rural residents as compared to urban residents. Notably, these were reported in high income countries. On the other hand, studies conducted in low and middle-income countries, reported a negative association where they indicated that there was a decrease in the odds of multimorbidity among residents in rural areas compared to urban context residents. Alternatively, these results suggested that those living in urban areas were at a higher risk of developing multimorbidity. Similar contrasting findings were reported 
in studies that evaluated socioeconomic disadvantage and multimorbidity at individual level in low income countries $(\underline{14}, \underline{22})$. This could be attributed to difficulties in access to and affordable primary health care that leads to low diagnosis and reporting (15). It could also be due to unhealthy behaviour and practices in urban areas which leads to ease of access to unhealthy foods, long working hours hence, lack of physical exercise with accessible health care facilities ()ㅡ, therefore increasing the reporting rate of multimorbidity. Additionally, the findings could be attributed to the epidemiological transition given that most of these findings were from low- and middle-income countries. From the study that tested the association between state-level education and multimorbidity and state-level income and multimorbidity, counterintuitive findings were reported. This suggest that individuals residing in states with lower education and lower income had a lower risk of developing multimorbidity as compared to their counterparts in states with higher education and higher income respectively. These findings are consistent with conclusions from studies that evaluated association between socioeconomic inequalities and multimorbidity in low- and middle-income countries (20, $\underline{43}$ ). These association may be due to complex underlying reasons like access to and utilisation of primary health care services. Thus, it could be that residents of high-income states have ease of access to affordable primary health care services, thus improved health seeking behaviour leading to early detection and reporting of multiple chronic diseases (15). Highly educated individuals would be able to secure well-paying jobs that enables earning high income which leads to improved access to healthcare facilities to seek care thus early diagnosis and better management of chronic diseases (15). It could also be due to improved economic and political power that promotes access to health care- well equipped health facilities with adequate number of General Practitioners who provide services effectively (15). On the other hand, residents of the low-educated and lowincome states would experience access and affordability challenges thus low reporting rates for multimorbidity. Therefore, with further research, disparities in reporting rates between states with high education level and low education level states may enhance understanding of the established negative association.

Since the available literature does not provide much information on the specific mechanisms by which area-level socioeconomic disadvantage impacts on multimorbidity, longitudinal studies to establish temporality or study causal mechanisms or address both may be necessary. The findings of such studies on the association between area-level socioeconomic disadvantage and multimorbidity, would provide information that could be used to substantiate the need for change, inform decision making and influence policy decisions and development of new health strategies and or approaches to prevent, manage and control multimorbidity using area-level population-based approach. In addition, studies may assess the types and extend of the chronic diseases of multimorbidity associated with different contexts to inform health resources distribution in effort to address multimorbidity. Nonetheless, decision makers may consider the findings in the current review, when designing and developing health promotion strategies and interventions for multimorbidity. 


\section{Conclusion}

In conclusion, we have found that an association between area-level socioeconomic disadvantage and multimorbidity exists. This indicates that an individual's neighbourhood may have an independent impact on their risk of developing multimorbidity. However, the quality of the included studies was mixed due to some methodological shortcomings. Regardless of the heterogeneity between included studies, it was evident that individuals who resided in areas that were less socio-economically advantaged were at high risk of multimorbidity as compared to those who resided in highly socioeconomically advantaged areas. However, the consistency in the direction of association depended on the exposure that was measured as an area-level socioeconomic disadvantage. Thus, it was established that the direction of association between area of residency and multimorbidity was mixed, whereas the direction of association between area deprivation and multimorbidity, state-education level and multimorbidity and state-income level and multimorbidity were consistent. Therefore, there is need for longitudinal studies to help establish temporality or causal mechanism to help influence policy.

\section{Conflict of Interest Statement}

The authors declare no conflicts of interests.

\section{About the Authors}

Micky Olutende Oloo is a researcher of the department of health promotion and sports science. His research interests are in health promotion especially the elderly.

Elizabeth Mse is the current chair in the department of health promotion and sports science, her researches interests are in the areas of nutrition and sports sciences.

Edwin Kadima Wamukoya is the dean school of public health and biomedical sciences Masinde Muliro university, he has a diverse experience in research and his current interests are in sports science and performance.

Maximilla Wanzala is the chair, department of public health, her research interests are in the area on Non communicable disease prevention.

\section{References}

1. Fortin M, Hudon C, Dubois MF, Almirall J, Lapointe L, Soubhi H. Comparative assessment of three different indices of multimorbidity for studies on healthrelated quality of life. Health Qual Life Outcomes. 2005;3:74.

2. Greene R, Dasso E, Ho S, Frank J, Scandrett G, Genaidy A. Patterns and expenditures of multi-morbidity in an insured working population in the United States: insights for a sustainable health care system and building healthier lives. Population health management. 2013;16(6):381-9. 
3. Chung RY, Mercer S, Lai FT, Yip BH, Wong MC, Wong SY. Socioeconomic Determinants of Multimorbidity: A Population-Based Household Survey of Hong Kong Chinese. PLoS One. 2015;10(10):e0140040.

4. Fortin M, Bravo G, Hudon C, Vanasse A, Lapointe L. Prevalence of multimorbidity among adults seen in family practice. Ann Fam Med. 2005;3.

5. Smith SM, Soubhi H, Fortin M, Hudon C, O'Dowd T. Managing patients with multimorbidity: systematic review of interventions in primary care and community settings. Bmj. 2012;345:e5205.

6. Afshar S, Roderick PJ, Kowal P, Dimitrov BD, Hill AG. Multimorbidity and the inequalities of global ageing: a cross-sectional study of 28 countries using the World Health Surveys. BMC Public Health. 2015.

7. Fortin M, Stewart M, Poitras ME, Almirall J, Maddocks H. A systematic review of prevalence studies on multimorbidity: toward a more uniform methodology. Ann Fam Med. 2012;10.

8. Smith SM, Wallace E, O'Dowd T, Fortin M. Interventions for improving outcomes in patients with multimorbidity in primary care and community settings. Cochrane Database Syst Rev. 2016;3:Cd006560.

9. Li J, Green M, Kearns B, Holding E, Smith C, Haywood A, et al. Patterns of multimorbidity and their association with health outcomes within Yorkshire, England: baseline results from the Yorkshire Health Study. BMC public health. 2016;16:649.

10. Violan C, Foguet-Boreu Q, Flores-Mateo G, Salisbury C, Blom J, Freitag M, et al. Prevalence, Determinants and Patterns of Multimorbidity in Primary Care: A Systematic Review of Observational Studies. PLOS ONE. 2014;9(7):e102149.

11. Mondor L, Cohen D, Khan AI, Wodchis WP. Income inequalities in multimorbidity prevalence in Ontario, Canada: a decomposition analysis of linked survey and health administrative data. International Journal for Equity in Health. 2018(1).

12. Sondergaard E, Willadsen TG, Guassora AD, Vestergaard M, Tomasdottir MO, Borgquist L, et al. Problems and challenges in relation to the treatment of patients with multimorbidity: General practitioners' views and attitudes. Scandinavian journal of primary health care. 2015;33(2):121-6.

13. Glynn LG, Valderas JM, Healy P, Burke E, Newell J, Gillespie P, et al. The prevalence of multimorbidity in primary care and its effect on health care utilization and cost. Fam Pract. 2011;28.

14. Khanam MA, Streatfield PK, Kabir ZN, Qiu C, Cornelius C, Wahlin A. Prevalence and patterns of multimorbidity among elderly people in rural Bangladesh: a crosssectional study. J Heal Popul Nutr. 2011;29.

15. Charlton J, Rudisill C, Bhattarai N, Gulliford M. Impact of deprivation on occurrence, outcomes and health care costs of people with multiple morbidity. Journal Of Health Services Research \& Policy. 2013;18(4):215-23. 
16. Barnett K, Mercer SW, Norbury M, Watt G, Wyke S, Guthrie B. Epidemiology of multimorbidity and implications for health care, research, and medical education: a cross-sectional study. Lancet. 2012;380.

17. Zulman DM, Pal Chee C, Wagner TH, Yoon J, Cohen DM, Holmes TH, et al. Multimorbidity and healthcare utilisation among high-cost patients in the US Veterans Affairs Health Care System. BMJ open. 2015;5(4):e007771.

18. Kuo RN, Lai MS. The influence of socio-economic status and multimorbidity patterns on healthcare costs: a six-year follow-up under a universal healthcare system. Int J Equity Health. 2013;12:69.

19. Bahler C, Huber CA, Brungger B, Reich O. Multimorbidity, health care utilization and costs in an elderly community-dwelling population: a claims data based observational study. BMC Health Serv Res. 2015;15:23.

20. Pathirana TI, Jackson CA. Socioeconomic status and multimorbidity: a systematic review and meta-analysis. Australian And New Zealand Journal Of Public Health. 2018;42(2):186-94.

21. Orueta JF, Garcia-Alvarez A, Alonso-Moran E, Vallejo-Torres L, Nuno-Solinis R. Socioeconomic variation in the burden of chronic conditions and health care provision - analyzing administrative individual level data from the Basque Country, Spain. BMC Public Health. 2013.

22. Ataguba J, Akazili J, McIntyre D. Socioeconomic-related health inequality in South Africa: evidence from General Household Surveys. Int J Equity health. 2011;10.

23. Katikireddi SV, Skivington K, Leyland AH, Hunt K, Mercer SW. The contribution of risk factors to socioeconomic inequalities in multimorbidity across the lifecourse: a longitudinal analysis of the Twenty-07 cohort. BMC Med. 2017;15(1):152.

24. von dem Knesebeck O, Bickel H, Fuchs A, Gensichen J, Hofels S, Riedel-Heller SG, et al. Social inequalities in patient-reported outcomes among older multimorbid patients--results of the MultiCare cohort study. Int J Equity Health. 2015;14:17.

25. Brewer N, Borman B, Sarfati D, Jeffreys M, Fleming ST, Cheng S, et al. Does comorbidity explain the ethnic inequalities in cervical cancer survival in New Zealand? A retrospective cohort study. BMC Cancer. 2011;11(1):132.

26. Stephanie A. Robert a. Community-Level Socioeconomic Status Effects on Adult Health. Journal of Health and Social Behavior. 1998(1):18.

27. Susanna S, Peter C, Sarah C. Modelling Inequality in Reported Long Term Illness in the UK: Combining Individual and Area Characteristics. Journal of Epidemiology and Community Health (1979-). 1996(3):366.

28. Pickett KE, Pearl M. Multilevel Analyses of Neighbourhood Socioeconomic Context and Health Outcomes: A Critical Review. Journal of Epidemiology and Community Health (1979-). 2001(2):111.

29. Coren E, Fisher M. The conduct of systematic research reviews for SCIE knowledge reviews. 2006.

30. Wells G SB, O'Connell D, Peterson J, Welch V, Losos M, et al. The NewcastleOttawa Scale (NOS) for assessing the quality of nonrandomised studies in meta- 
analyses

[06/08/2018].

Available

from:

http://www.ohri.ca/programs/clinical epidemiology/oxford.asp. 2004.

31. PRISMA. Preferred Reporting Items for Systematic Reviews and Meta-Analyses. Accessed from: http://www.prisma-statement.org/.

32. Salisbury C, Johnson L, Purdy S, Valderas JM, Montgomery AA. Epidemiology and impact of multimorbidity in primary care: A retrospective cohort study. British Journal of General Practice. 2011;61(582):e12-e21.

33. Barnett K, Mercer SW, Norbury M, Watt G, Wyke S, Guthrie B. Epidemiology of multimorbidity and implications for health care, research, and medical education: a cross-sectional study. Lancet. 2012;380(9836):37-43.

34. Roberts KC, Rao DP, Bennett TL, Loukine L, Jayaraman GC. Prevalence and patterns of chronic disease multimorbidity and associated determinants in Canada. Health promotion and chronic disease prevention in Canada : research, policy and practice. 2015;35(6):87-94.

35. Orueta JF, Alonso-Moran E, Nuno-Solinis R, Alday-Jurado A, Gutierrez-Fraile E, Garcia-Alvarez A. Prevalence and costs of chronicity and multimorbidity in the population covered by the Basque public telecare service

36. Prevalencia de cronicidad y multimorbilidad en la poblacion cubierta por el servicio publico de teleasistencia de Euskadi: Impacto en costes y calidad de la atencion. Anales del sistema sanitario de Navarra. 2013;36(3):429-40.

36. Prazeres F, Santiago L. Prevalence of multimorbidity in the adult population attending primary care in Portugal: a cross-sectional study. BMJ open. 2015;5(9):e009287.

37. Nunes BP, Chiavegatto ADP, Pati S, Teixeira DSC, Flores TR, Camargo-Figuera FA, et al. Contextual and individual inequalities of multimorbidity in Brazilian adults: a cross-sectional national-based study. BMJ open. 2017;7(6).

38. Wang S, D'Arcy C, Yu Y, Li B, Liu Y, Tao Y, et al. Prevalence and patterns of multimorbidity in northeastern China: a cross-sectional study. Public health. 2015;129(11):1539-46.

39. Alaba $\mathrm{O}$, Chola L. The social determinants of multimorbidity in South Africa. International Journal for Equity in Health. 2013;12(1):63.

40. Wang SB, D'Arcy C, Yu YQ, Li B, Liu YW, Tao YC, et al. Prevalence and patterns of multimorbidity in northeastern China: a cross-sectional study. Public health. 2015;129(11):1539-46.

41. Salisbury C, Johnson L, Purdy S, Valderas JM, Montgomery AA. Epidemiology and impact of multimorbidity in primary care: a retrospective cohort study. 2011:18.

42. Orueta JF, Nuno-Solinis R, Garcia-Alvarez A, Alonso-Moran E. Prevalence of multimorbidity according to the deprivation level among the elderly in the Basque Country. BMC Public Health. 2013;13:918.

43. Pati S, Agrawal S, Swain S, Lee JT, Vellakkal S, Hussain MA, et al. Non communicable disease multimorbidity and associated health care utilization and expenditures in India: cross-sectional study. BMC Health Serv Res. 2014;14:451. 
Creative Commons licensing terms

Authors will retain the copyright of their published articles agreeing that a Creative Commons Attribution 4.0 International License (CC BY 4.0) terms will be applied to their work. Under the terms of this license, no permission is required from the author(s) or publisher for members of the community to copy, distribute, transmit or adapt the article content, providing a proper, prominent and unambiguous attribution to the authors in a manner that makes clear that the materials are being reused under permission of a Creative Commons License. Views, opinions and conclusions expressed in this research article are views, opinions and conclusions of the author(s). Open Access Publishing Group and European Journal of Physical Education and Sport Science shall not be responsible or answerable for any loss, damage or liability caused in relation to/arising out of conflict of interests, copyright violations and inappropriate or inaccurate use of any kind content related or integrated on the research work. All the published works are meeting the Open Access Publishing requirements and can be freely accessed, shared, modified, distributed and used in educational, commercial and non-commercial purposes under a Creative Commons attribution 4.0 International License (CC BY 4.0). 